OPEN ACCESS

Citation: Matthew E. Bergman, Gianluca Passarelli, Fabio Serricchio (2020) Decades of Party Distrust. Persistence through Reform in Italy. Quaderni dell'Osservatorio elettorale - Italian Journal of Electoral Studies 83(2): 15-25. doi: 10.36253/qoe-9590

Received: August 11, 2020

Accepted: November 17, 2020

Published: January 23, 2021

Copyright: @2020 Matthew E. Bergman, Gianluca Passarelli, Fabio Serricchio. This is an open access, peer-reviewed article published by Firenze University Press (http://www.fupress.com/qoe) and distributed under the terms of the Creative Commons Attribution License, which permits unrestricted use, distribution, and reproduction in any medium, provided the original author and source are credited.

Data Availability Statement: All relevant data are within the paper and its Supporting Information files.

Competing Interests: The Author(s) declare(s) no conflict of interest.

\section{Decades of Party Distrust. Persistence through Reform in Italy}

\author{
Matthew E. Bergman ${ }^{1, *}$, Gianluca Passarelli ${ }^{2}$, Fabio Serricchio ${ }^{3}$ \\ ${ }^{1}$ University of Vienna, Austria, 0000-0001-8879-4615 \\ ${ }^{2}$ Sapienza University, Italy, 000-0002-3300-0790 \\ ${ }^{3}$ University of Molise, Italy, 0000-0003-0913-9722 \\ ${ }^{\star}$ Corresponding author. E-mail: Matthew.Bergman@univie.ac.at
}

\begin{abstract}
One common feature of the Italian political space over the past half century has been the presence of distrust in political parties and the presence of anti-system parties on both the left and the right. Discontent with existing elites and the political system has taken many forms, including referendums altering the electoral system. Both the character of the main parties and the rules by which they are elected have been reformed 4 times since the 1980s. However, as the elections of 2013 and 2018 and the referendum of 2016 demonstrate, Italians still have a high amount of resentment towards party elites and the operation of the system. Using data from Italian National Election Studies, this paper traces the development of this party resentment with a focus on three questions: 1) How has resentment towards party representiveness changed with the electoral and party reforms 2) Who was likely to hold this resentment 3) What was the party affiliation of those most resentful, or did they abstain? Results stress that socio-demographic differences had little effect on understanding the source of party resentment; distrust in parties correlates well with distrust in parliament and political administration. General social distrust did not translate into a distrust for parties. We conclude that discontent can be separated into a political dimension associated with current governance and one of a more systemic nature.
\end{abstract}

Keywords. Political parties, protest voting, party distrust, Italy.

\section{INTRODUCTION}

One common feature of the Italian political space over the past half century has been the distrust of political elites and presence of anti-system parties on both the left and the right. This elite discontent and frustration with political system has taken many forms, including referendums altering the electoral system (Bergman and Passarelli 2021). Both the character of the main parties and the rules by which they are elected have been reformed four times since the 1980s. However, with the continuing success of "antiparty" parties (Mudde 1996) the elections of 2013 and 2018 and the referendum of 2016 demonstrate (Bergman and Passarelli 2021), Italians still have a high amount of resentment towards party elites and the operation of the system. Using data from Italian National Election Studies, this paper examines 
correlates with this resentment over a period of time ranging from 1968 to 2018 with a focus on three main questions: (1) How has resentment towards party representativeness changed with electoral and party reforms? (2) Who was likely to hold party resentment? (3) What was the party affiliation of those most resentful, or did they abstain?

After introducing the concept of party discontent, the Italian case, and our dataset, results indicate that sociodemographic differences have little explanative effect on understanding the source of party resentment; distrust in parties correlates well with distrust in parliament and political administration. General social distrust did not translate into a distrust for parties. While electoral reform had little impact, the partisan emergence of the Five Star movement has provided a party for those with anti-party sentiments to vote for. Our conclusions provide support for the notion that discontent can be separated into a political dimension associated with current governance and one of a more systemic nature (Bergman and Passarelli 2021; Passarelli and Tuorto 2018).

\section{PARTY DISCONTENT}

Political discontent and mistrust towards political parties is not only a contemporary phenomenon. The negative attitudes of people (citizens and voters alike) are somewhat ontologically linked to the nature of the political parties. Since the ancient Roman and Greek polis, people maintained controversial attitudes towards the political groups that led the governments of those still early societies. As Piero Ignazi notes - echoing Giovanni Sartori (1976) - most of the problem lays on the name: "party has a bad etymology. It comes from the Latin verb partire meaning to divide, and from the derived noun pars, which means part. Thus, part contains the genetic code of partiality and division» (2017, p. 1). While the divisions created by partisanship have been longstanding, it is quite recent that this political phenomenon has been the object of academic interest in a comparative manner (Gidron et al 2020). Since the seventies, a notable anti-party anti-politic sentiment has been present in European political space (Mudde 1996). Political parties' legitimacy had begun to be questioned. Moreover, after a period of comparatively high trust, especially after WWII in countries who completed the transition ${ }^{1}$ from authoritarian and totalitarian regimes

\footnotetext{
${ }^{1}$ Different interpretations are reported by authors claiming that the political transition to democracy has generated the increase of the anti-party sentiment, as happened in Germany after 1989 or Spain after 1977 (see Torcal, Gunther and Montero, 2001, p. 4).
}

to democracy, more critical views of the political parties took hold as political parties began to be a source of shame (Dalton, 1996; Mair, 1995). If the negative sentiments towards political parties persist in most of the advanced democracies, then this distrust cannot arise from the negative evaluation of a single party nor its performance. Instead, the "criticism points also, even if not explicitly, to [the party's] nature, more than its role» (Ignazi, 2017, p. 1).

In order to better detect the phenomena of political party discontent (Daalder, 2002) it is crucial to first define what anti-party sentiment is. Poguntke and Scarrow have indicated a two-fold meaningful distinction to tackle the anti-party attitude. They have distinguished between the 1) elite level and the 2) mass level (1996). In the first case, the anti-party sentiment (élite) «presents itself in the form of criticisms concerning the current roles of parties in democratic systems [...] such criticisms may be presented in the language of democratic theory (Poguntke and Scarrow, 1996, pp. 257-258). On the one hand, «this expectation inevitably leads to a negative evaluation of the role of political parties as distorting intermediaries between politicians and the general will». On the other side, «those who see a strong and effective state as the guarantor of the common good view parties as troublemakers which undermine the capacities of the state». The second level of anti-party system (mass level) can be defined as «inspired, amplified and fueled by antiparty theorizing by intellectual and political elites» (ibid).

The anti-party sentiment is then different from protest voting or feelings (Schedler, 1996). Protest voting represents an attempt to scare the élite, extant political parties, the incumbent, or democratic institutions as whole. Although it is possible to detect a few similarities and points of contact between these related concepts, it is evident that they refer to different political phenomena. A protest vote can be policy driven, and it is usually affected by short-term factors, such as the economic performance and the incumbents' role (Lewis-Beck and Paldam, 2000). In electoral terms, protest is expressed through a vote against the party voters supported in the past and/or against the elite at the government (Klingemann and Fuchs, 1995). Electoral volatility is an indicator of "protest", but in and of itself is not sufficient evidence of anti-party sentiment, as supporting alternative longstanding political parties does not demonstrate an antagonism towards them.

Anti-party sentiment, therefore, cannot be expressed directly through electoral behavior. Anti-party sentiment is addressed to "politics", to political parties beyond a single actor, and the policies approved or discussed by these actors. 
Having defined anti-party sentiment, two general approaches have been adopted to measure this attitude: The first takes an "index" approach of anti-party sentiment by aggregating different survey items. Torcal and Montero (2006) adopt this index approach, using the following items to measure the party discontent: " (1) Parties criticize one another, but in reality they are all alike. (2) Political parties only divide people. (3) Without parties, there can be no democracy. (4) Parties are needed to defend the interests of various groups and social classes. (5) Thanks to parties, people can participate in political life. (6) Parties are useless.» An alternative specification, directly detects the anti-party attitudes through precisely worded survey questions (e.g. trust on parties). In particular, scholars usually examine antiparty sentiment as an independent variable in analyzing survey results explaining "Party identification", and "Party Sentiment" 2 . Here, we seek to flip this standard approach, and examine the correlations placing anti-party sentiment as the dependent variable.

\section{THE ITALIAN CASE: PARTY RESENTMENT AFTER LUKEWARM SENTIMENTS}

Italy represents a peculiar case where there has been comparatively both high level of party membership, party identification, and anti-party sentiment (Bardi, 1996; De Petris and Poguntke, 2015; Morlino and Tarchi, 1996). Since WWII, Italy has been characterized by high electoral participation and political parties served as crucial actors in leading almost all aspects of the social life; albeit at the same time, they were also subjects of mistrust. In fact, one common feature of the Italian political space over the past half century has been the presence of anti-system parties on both the left and the right. Discontent with existing elites and the political system, has more than once, and resulted in referendumbased reforms to the political system. Both the character of the main parties and the rules by which they are elected have been reformed 4 times since the 1980s (Passarelli, 2018, p. 862). However, as the general elections of 2013 and 2018 and the referendum of 2016 demonstrate, Italians have a high amount of resentment towards party elites and the operation of the system (Bergman, 2019). Our first question seeks to examine the development of party discontent over-time and whether this has been impacted by different parties or electoral systems. The grey line on Figure 1 displays the low level and decreasing trust in political parties. Conversely during these

${ }^{2}$ The Italian National Election Survey uses this approach.

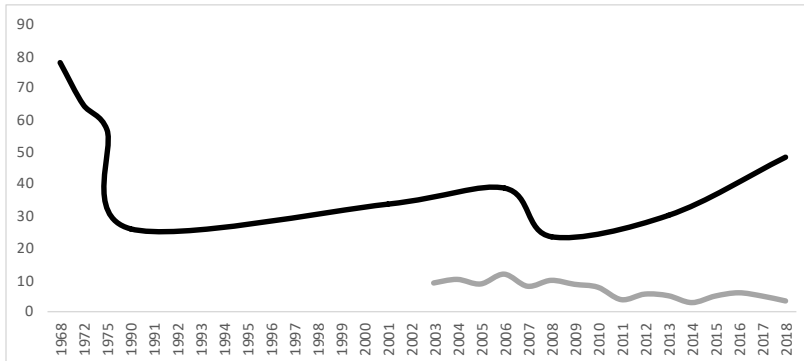

Figure 1. Trust in Political Parties and Party Identification in Italy (1968-2018). Source: Demopolis (several years); Bellucci e Segatti (2008); Itanes (1968-2018). Legend: black line refers to the Party identification (very + quite close); The grey line indicates the rate of trust in political parties (High + enough trust). Total on Italian voters.

more recent years, party identification has increased as evidenced by the black line in Figure $1^{3}$.

The two most recent general elections (2013 and 2018) have seen new political forces channeling antiparty sentiments gain a large share of voters. In 2013 a new party - the Five Star Movement (M5S) - obtained about one quarter of the votes in its first national parliamentary election. Its political agenda was founded on anti-party sentiment, not only against the incumbents, but also against all the "old" parties per se, both considered to be negative for the country. In 2018 the M5S collected more than 30 per cent of the national votes, making it the largest single party in the Italian parliament. In the same year, another historical anti-party movement increased its vote share: the Northern league (LN) obtained about $17 \%$ of votes. Two years earlier, in 2016, there had been a constitutional referendum, which intended to amend the bicameral nature of policy-making. 60 per cent of voters did not support the proposal of changes and studies say that voters decided on the basis of a protest against the elite and the prime minister in charge, Matteo Renzi (Bergman, 2019).

As argued by Sani and Segatti (2001), an explanation for the temporal stability of anti-party sentiment over time are rather well rooted in the Italian political culture. Concern over the long-term anti-party sentiment trend, well known in many contemporary democracies (Van der Meer 2017), has coupled its effects in the Italian context where the national trend towards mistrust for parties was already in place. Therefore, in Italy, there has been an increasing tension between professional political elites and the citizens. Nevertheless, Italy was seemingly characterized by stable electoral behaviors, comparatively high level of political participation, and high turnout.

${ }^{3}$ Probably due to the polarization effect. 
These decades of partisan stability were mainly driven by the ideological positioning and electoral challenge between the Communists and the anti-communists, broadly grouped around the Christian democrats. After 1989 and fall of the Berlin Wall, judicial investigations indicted most of the former parties who had governed in an anti-communist coalition since 1948. This offered the chance for new parties to appear. The early performance of the Northern Leagues, the communists' transition towards a social-democratic ideology, and the birth of Forza Italia - the party owned by the tv tycoon Silvio Berlusconi - radically modified the once stable party system (Bellucci and Segatti, 2010). Those social and political changes paved the way for electoral reform - from a proportional open list toward mixed-member majoritarian - that was characterized by periods of increasing electoral volatility (Passarelli, 2018). From 1994 the party system evolved from a multiparty structure towards a more bipolarized format around two big (catch-all) coalitions, one from the centreleft and the other from the centre-right. The latter pattern stood until 2013, when as previously mentioned, the M5S appeared on the political stage and refused coalition with any other party, increasing party fragmentation, and introducing a tri-polarization of political space. This structure was reaffirmed during the 2018 election ${ }^{4}$. On the electoral side, Italian turnout has only slightly decreased, though remained comparatively high (over $70 \%$ ).

These party system's changes were in concert with a highly unstable electoral system. Since the 1990s, the system has been reformed four times in an attempt to stabilize the party system through altering the rules of translating votes into seats. As discussed above, this goal was not reached and new parties continued to proliferate. Party system instability and voters' disaffection towards parties persist especially towards traditional political forces.

The electoral and party reforms discussed above might have led to changes in attitudes towards party representativeness and the partisan identification of voters holding anti-party sentiments - questions 1 and 3 of our purpose. We now introduce the variables that can help identify which other characteristics of voters might correlate with anti-party sentiment.

\section{SOURCES OF DISTRUST}

As discussed above, we situate anti-party sentiment as our dependent variable and we aim to explain the fac-

\footnotetext{
${ }^{4}$ In post-election bargaining, however, M5S broke with its no-coalition promise and joined with the LN, another anti-party party in a coalition government.
}

tors correlated with it. On a general stand it is assumed that anti-party attitudes are related to a decrease in generic support for the democratic regime and the way that existing parties limit the critical role of citizens (Norris 1999). In the Italian context, Sani and Segatti (2001) have indicated that anti-party sentiments coexist with high levels of party identification and high levels of support for the democratic regime. We propose the following correlates with anti-party sentiment in Italy and later analyze them in a diachronic perspective.

\section{1: greater democratic disaffection correlates with} greater anti-party sentiment

Mistrust of democracy might lead to mistrust of the parties operating within it. We expect that in the Italian case, as Sani and Segatti have pointed out (2001), this relation is consistently negative (Maraffi, 2007).

\section{2: those abstaining from electoral involvement} have greater anti-party sentiment

Voters and citizens who are not satisfied with the institutional performance are usually considered to be keener to express their protest in different ways, including abstaining from the political process (Hirschman, $1970)^{5}$. In this manner, they can express antagonism towards the incumbent or protesting without necessarily being antagonistic towards democracy (Katsanidou and Eder, 2018). We expect that abstaining will be positively related with anti-party sentiment.

C. 3: lower trust in Parliament correlates with higher anti-party sentiment.

Those people who show low levels of trust towards the representative institutions also express low trust towards political parties (Torcal and Montero, 2006). Negative attitudes towards the Parliament, who is the ultimate place where political parties express their identities, should be associated with a lower level of trust in political parties ${ }^{6}$.

C. 4: lower trust in others (social capital) correlates with higher the anti-party sentiment

As the extensive literature on social capital argues, (horizontal) trust in other community members can intensify feelings of (vertical) trust in political institutions and political parties themselves (Cartocci, 2007; Putnam, 2000; Warren, 2018). As with correlate \# 3, the

\footnotetext{
${ }^{5}$ Kang (2004) has also measured the effect as influenced by different electoral systems.

${ }^{6}$ Public administration may also been seen as an avenue for parties to express their competence. Negative attitudes towards public administration should also be associated with a lower level of trust in political parties.
} 
voters who are less keen to trust others and so show less social capital/trust, should be associated with a higher levels of party discontent.

Moreover, it is important to consider political parties and their link to voters. In this light, we suggest three further correlations.

C. 5: greater attachment to political parties is correlated with lower anti-party sentiment.

From a theoretical point of view, we expect that being closer to a political party should generate a lower level of party discontent and mistrust. However, this is not always the case, as the Italy context has demonstrated (Sani and Segatti, 2001). Therefore, we shall verify whether this relation keeps its expected direction when subjected to multivariate analysis or whether it has changed overtime.

C. 6: party membership is particularly correlated with lower anti-party sentiment

As for the party identification, we expect that those who are enrolled as party members will be less critical towards political parties. Being part of the "political community" should in fact induce party members to be less critical towards organization to which they belong.

C7: voters for anti-system parties are correlated with greater anti-party sentiment

It has been argued that lower levels of political trust are correlated with voting for protest parties, serving as a 'safety valve' of political discontent in the Belgian case (Hooghe and Dassonneville, 2018). Similarly, in Italy, we expect that a party (like the M5S or LN) that stresses anti-politics attitudes and policies should have voters that also express negative feeling towards politics, institutions and political parties as intermediate actors between citizens and democratic institutions.

C. 8: voting in proportional elections is correlated with lower anti-party sentiments

As the electoral system offers opportunities and constrains to voters and to political parties, we can expect that with PR electoral systems (2005-2013), negative feeling towards parties could have been ameliorated, at the least in terms of representation; that is voters could support an anti-party party and expect it to gain electoral representation.

We will examine these correlations in a bivariate and multivariate analysis controlling for socio-demographic variables such as age, gender, education, ideological self-placement on a left-right scale, and geograph- ic location (via random effects). We also include which party a respondent indicated they voted for to examine the effect of the presence or absence of anti-party parties (LN and M5S)

\section{OPERATIONALIZATION}

We examine these correlations through the use of ITANES post-election survey data. Our primary dependent variable is asked after each election: "tell me how much you trust each of the following institutions [parties]: not at all, a little, somewhat, very much". Given the nature of this variable (1-4), an ordered logistic regression will be used in analysis to compare our theoretical explanations. These surveys also include many of the covariates we are interested in. These include gender, education, age, importance of religion, left-right ideology, employment and voting behavior.

We operationalize our correlations as follows:

- C1 democratic dissatisfaction: believes to be true that "people like me have no influence on what the government does"; 7

- C2 abstention: respondent did not vote in the election;

- C3 distrust in parliament ${ }^{8}$ : level of distrust in parliament;

- C4 low social capital: if respondent agrees that "you are never prudent enough with people";

- C5 strong party identification: if respondent feels close to a political party;

- C6 party member: if respondent is or was a member of a political party;

- C7 anti-system party voter: if respondent voted for LN or M5S;

- C8 electoral system: if respondent voted between 2005 and 2013.

\section{FINDINGS}

There are three questions that we answer: (1) How has resentment towards elites and systemic party representativeness changed with the electoral and party reforms? (2) Who was likely to hold this resentment? (3) What was the party affiliation of those most resentful, or did they abstain?

\footnotetext{
${ }^{7}$ Although this variable is used to measure political efficacy in other ITANES studies, we here use it as a proxy for democratic dissatisfaction ${ }^{8}$ Distrust in public administration is also included for years 2001 and 2006 when the question was included on the ITANES post-election survey.
} 
We first present cross-tabulation analysis on elections from 2001 onward to 2018 and then multivariate analysis. In this time period, the party system and the electoral system have changed several times. The 2001 election used a mixed-member system. The center-right House of Freedom coalition of Forza Italia, National Alliance, Northern League, Christen Democrats, and three smaller parties challenged the Olive Tree coalition of Democrats of the Left, The Daisy, and three smaller parties. The Communist Refoundation Party and Italy of Values served as alternative party choices to the large coalitions.

The elections of 2006 and 2008 were cast using a PR system with a bonus for the largest coalition. The parties of the left all united into the Union coalition to challenge the center-right House of Freedoms. The 2008 election simplified the party system as Forza Italia merged with the National Alliance and the Daisy and Democrats of the Left merged into the Democratic Party.

2013 saw the emergence of a centrist grouping With Monti for Italy - and populist protest movement - 5 Star Movement. The former performed below expectations while the later provided a vessel to channel protest and the party became the largest one after elections. 2018 saw the creation of yet another electoral system consisting of multi-member constituencies. After the election, the League outpolled Forza Italia and joined into alliance with the 5-star movement. The variety of electoral systems and party constellations provides a variety of institutional arrangements that might be the source of political distrust.

Figure 2 presents the mean and standard deviations of the dependent variable: distrust in parties. Recall that a " 4 " means "not at all" trusting of political parties and "1" means "very much" trust in political parties. The elections in the 2000s all had a similar level of distrust. Most voters noted having "a little" trust in political parties. The rise of the 5 Star Movement in 2013 and $2018^{9}$ exemplifies a greater level of distrust among the Italian public (Passarelli and Tuorto, 2015; 2018). The amount of distrust of political parties has risen steadily in the 2010s. This provides some evidence that the rise of a tripolar system with the 5-star movement might be associated with increased distrust in political parties. Subsequent analyses will examine this claim further.

Next, Figure 3 presents the level of distrust by party voted for in the Chamber of Deputies. The trendlines

\footnotetext{
9 The scale was resized to 1-4 from 1-10 in 2018. ITANES provides 4 possible responses to this variable: not at all, a little, somewhat, very much. However, in the 2018 survey they asked respondents to answer on a scale from 1-10. On the figure, we kept 1 as the minimal and divided all other values by 2.5 , which would bring the maximum value to 4 .
}

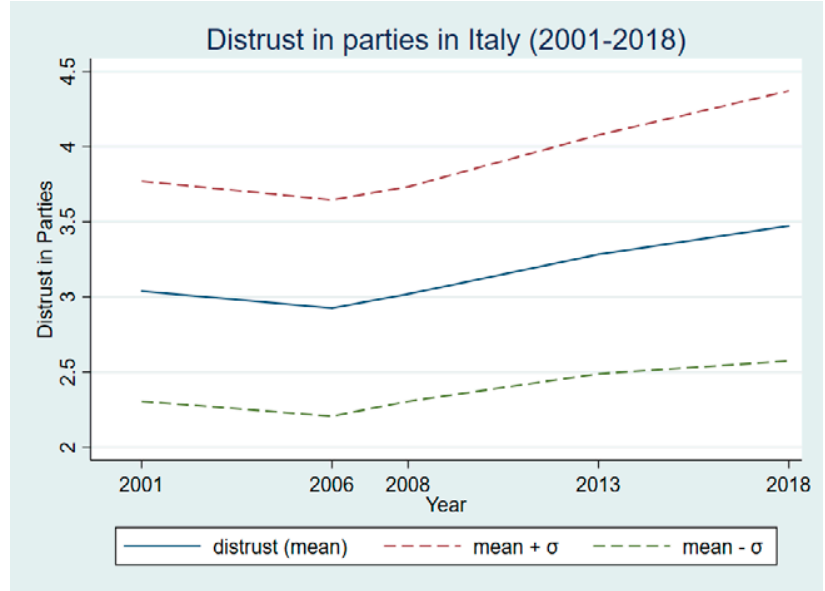

Figure 2. Political Distrust over Time (Source ITANES 2001-2018).

show how the voters for each political grouping have changed in their distrust over time. In 2001, the parties on the right had greater amounts of distrust than those on the left. Forza Italia voters had the greatest levels of distrust of parties. Berlusconi led this coalition of center-right voters and was elected Prime Minister. In 2006, this pattern continues, with center-right voters expressing greater amounts of distrust then those on the left. However, by 2008, this pattern is no longer detectable. Center-right voters slightly decreased in their overall distrust while center-left voters increased in their levels of distrust. For context, between these years, the center-left was elected into office, but coalition dynamics brought down the government early.

A technocratic government supported by the centrist parties had been installed in 2011, yet by 2013 all partisan voters increased their level of distrust. Most notably, the 5 Star Movement's voters in both 2013 and 2018 exhibit expressly greater levels of distrust. This party stands above the others with its level of distrust. The overall level of distrust in these election years is correlated with the great performance of this party. The far-right League voters also by 2018 have distinctly higher levels of distrust. These two parties joined into a governing coalition in 2018. With greatly different ideologies, they are however joined in their anti-establishment positions.

One of our main questions of interest is whether an individual respondent feels close to a party. We are able to go further back in time with the ITANES data on this question. Results are presented in tables 1-3. Table 1 demonstrates a steady trend of respondents not feeling close to any particular party. With the exception of 1990 (during the breakup of the old party system), the past two decades have seen only about half the individuals as in previous decades expressing attachment to a political party. 


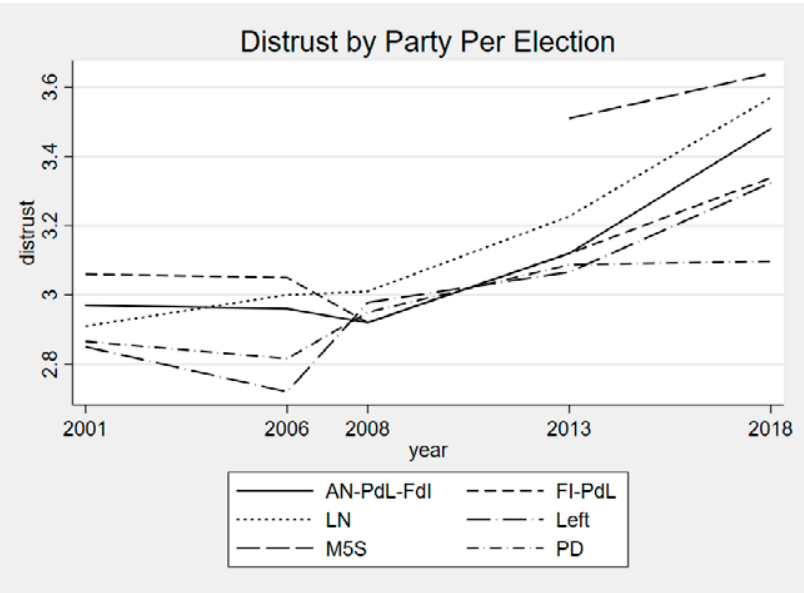

Figure 3. Distrust by Party Over Time (Source ITANES 2001-2018).

Table 2 introduces a potential co-variate: region. A pattern of decline can be detected across the nation, although some regional differences are evident. Overall, Italy faced between 12 and 13 point drop in party affinity, with a low point in the mid-2000s. From the high in 1968, the North-East experienced the greatest decrease in party affinity - with 1 in 5 respondents losing a party attachment. On the other-hand, the Red Zone, with its traditional attachment to parties of the left expressed only a 7 point drop. Another regional difference to note is that after the 2005 electoral reform, the Northern regions experienced an increase in party attachment, reversing the steady downward trend. From a lowpoint in 2008, all regions expressed an increase in party attachment in the 2013 election, the first national election that the 5 star movement contested winning $25 \%$ of the vote.

Table 3 identifies if there is any age cohort effectsthat is, can we attribute the decline in party attachment to specific age cohorts? Do respondents born later have less attachment than their elders? Here too, the answer appears to be no. All age cohorts dropped by at least $30 \mathrm{pp}$. Younger cohorts actually have greater connection to parties in the current era (Kestilä-Kekkonen, 2009). This may be because older parties have been dissolved. It does present a brief conundrum, however. If younger voters have grown up with the existing parties, perhaps they will feel a stronger connection. It is also worth noting that those born during the WWII-era previously had lower than average party identification, while in the contemporary era, they are the most connected.

Summary statistics for all variables used in analysis are presented in the appendix along with a table of bivariate correlations. We now turn to regression analysis to answer our final question, of what are the indi-
Table 1. Party Identification Over Time.

\begin{tabular}{lccccccccccc}
\hline$\%$ & 1968 & 1972 & 1975 & 1990 & 2001 & 2006 & 2008 & 2013 & 2018 \\
\hline Very + quite close & 77.8 & 64.5 & 56.8 & 25.8 & 33.5 & 38.5 & 23.3 & 30.0 & 48.2 \\
Only sympathizer & 5.4 & 7.0 & 12.0 & 23.5 & 21.3 & 16.9 & 27.9 & 43.5 & 22.6 \\
Not close & 16.7 & 28.5 & 31.2 & 50.7 & 45.2 & 44.6 & 48.9 & 26.4 & 29.2
\end{tabular}

Source: adaptation from Biorcio, 2008-2018 (Itanes).

Table 2. Party Identifiers by Region across years (closeness to a party) (\% Very + quite close+symp).

\begin{tabular}{lccccccccc}
\hline & 1968 & 1972 & 1975 & 1990 & 2001 & 2006 & 2008 & 2013 & 2018 \\
\hline North-west & 85.9 & 74.6 & 64.9 & 49.1 & 54.5 & 61.5 & 53.1 & 77.0 & 72.5 \\
North-east & 90.0 & 73.7 & 71.2 & 35.4 & 46.9 & 50.6 & 56.1 & 70.8 & 70.9 \\
Red zone & 77.1 & 65.6 & 66.1 & 56.3 & 64.7 & 57.6 & 55.1 & 75.2 & 69,9 \\
Center & 82 & 69.7 & 75.6 & 50.4 & 57.8 & 52.8 & 52.7 & 72.6 & 67.4 \\
South & 82.7 & 71.7 & 70.2 & 51.9 & 50.7 & 51.9 & 45.6 & 71.5 & 71.2 \\
Italy & 83.2 & 71.5 & 68.8 & 49.3 & 54.8 & 55.4 & 51.2 & 73.5 & 70.8 \\
\hline
\end{tabular}

Source: adaptation from Biorcio, 2008-2018 (Itanes).

Table 3 Party identifiers by age cohort in Italy across years (closeness to a party) (\% Very + quite close+symp).

\begin{tabular}{lccccccccc}
\hline & 1968 & 1972 & 1975 & 1990 & 2001 & 2006 & 2008 & 2013 & 2018 \\
\hline Until 1925 & 83.2 & 73.2 & 67.3 & 51.8 & 48.4 & 42.3 & 44.7 & 60.0 & - \\
$1926-1935$ & 82.8 & 71.1 & 67.7 & 45.1 & 54.5 & 48.6 & 48.3 & 79.7 & $*$ \\
$1936-1945$ & 83.4 & 65.7 & 69.4 & 47.6 & 56.6 & 53.1 & 53.2 & 80.9 & 92.3 \\
$1946-1955$ & 83.7 & 75.5 & 72.9 & 53.5 & 57.9 & 62.2 & 51.5 & 76.5 & 71.9 \\
$1956-1965$ & & & 66.1 & 46.8 & 53.0 & 55.9 & 50.2 & 73.2 & 69.5 \\
$1966-1975$ & & & & 50.7 & 56.8 & 58.3 & 49.4 & 69.9 & 66.4 \\
$1976-1985$ & & & & & 51.5 & 54.1 & 54.3 & 73.0 & 74.4 \\
$1986-1995$ & & & & & & & & 67.7 & 71.3 \\
$1995-2000$ & & & & & & & & & 87.5 \\
Italy & 83.2 & 71.5 & 68.8 & 49.3 & 54.8 & 55.4 & 51.2 & 73.5 & 70.8 \\
\hline
\end{tabular}

Source: adaptation from Biorcio, 2008 (Itanes).

* Less than five cases.

vidual characteristics of voters that have higher levels of distrust. Four category ordered logistic regression will be used for 2001, 2006, 2008, and 2013. Because respondents could provide a 1-10 range in 2018, this year includes a 10 category ordered logistic regression. For ease of interpretation, coefficient plots identify which variables are statistically significant by the confidence intervals of their estimated effect being statistically different from 0 . All models include random-effects at the regional level to control for regional variation that is not covered by our individual-level indicators, such as differences in the party system or historical legacies. Full regression output is presented in the online appendix. 

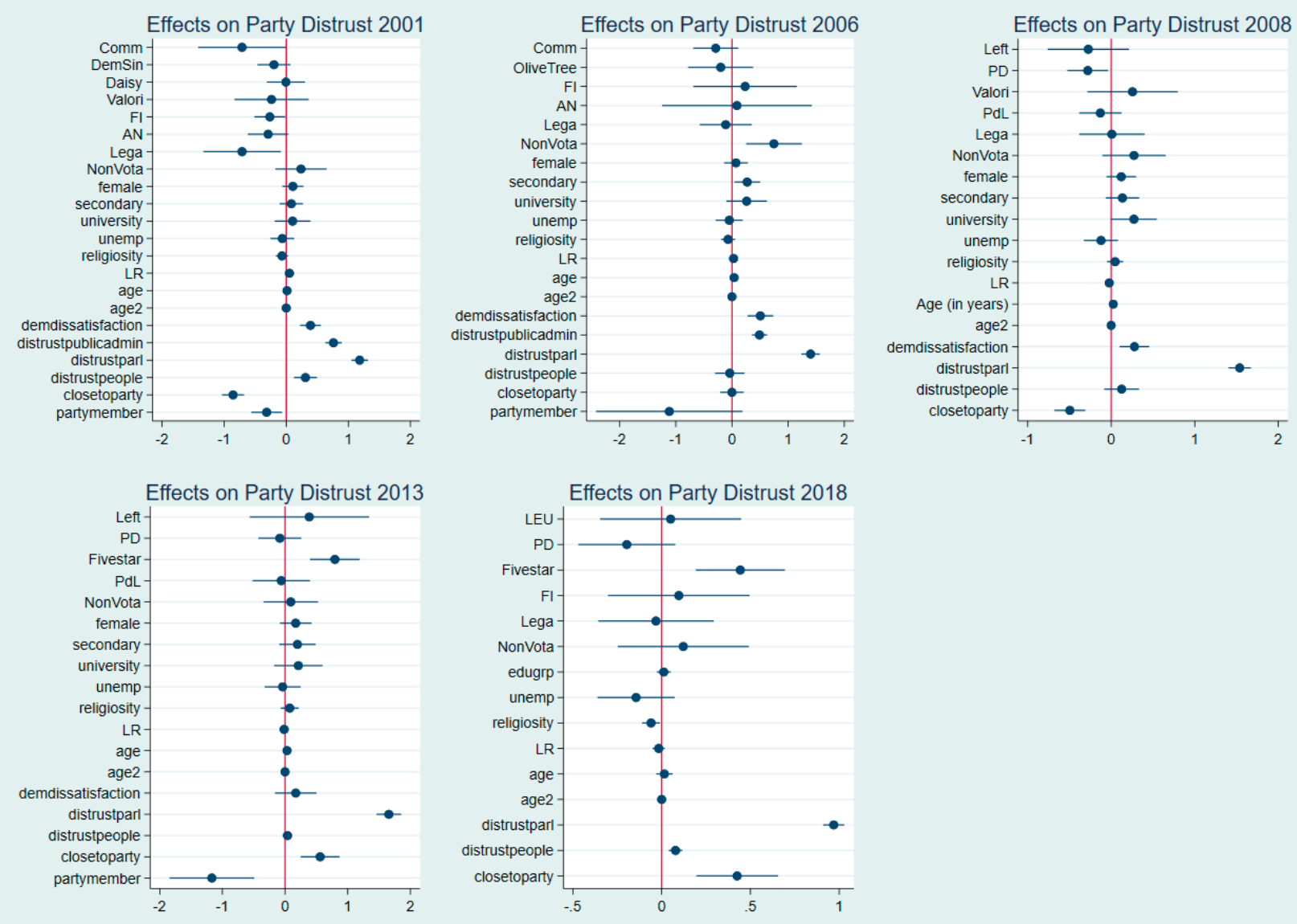

Figure 4. Effects on Party Distrust 2001-2018.

Figure 4 indicates that partisan and abstaining differences in anti-party sentiment was minimal in 2001. Lega and Forza Italia voters seem to show less trust than voters for smaller parties or those wishing not to answer ${ }^{10}$. Radical left voters also have lower levels of trust. This should be balanced against the finding that voters who identify further to the right have greater amounts of distrust in parties. None of the socio-demographic controls have significance. However, each of our predicted correlations is supported. Those who do not believe that democracy is empowering, that lack confidence in government administration, that lack confidence in parliament and others express greater levels of distrust towards parties. On the other hand, those who do feel close to a particular party or who are party members have greater amounts of political trust in parties. Assessment of each of our individual predictive variables

\footnotetext{
${ }^{10}$ The baseline for our regression models are the voters for minor parties. All regression models include random effects for region.
}

are summarized on Table 4 after the discussion here of whether electoral or party reform or partisan identification/abstention has an effect in each specific year.

The results from 2006 are slightly less supportive of expectations, although we are not too surprised by results. Of all major party groupings, only abstainers have a statistical difference in the amount of trust in parties. This election was the first performed with the new electoral system. Parties all joined into two coalitions, and as such, individual party identities and histories might have less importance. With all parties joining into coalitions, partisans could not express distrust by voting for any party over others than abstaining. In the 2008 election, with results that follow similarly to the previous election. Again, those who feel close to a party express greater trust in parties with those voting for the newly formed Democratic Party, in-power from 2006, expressing an even greater trust than voters for minor parties.

The emergence of the anti-party " 5 Star Movement" in the 2013 election produced a great change in 
the effects of our predicted variables. Voters for the 5 Star Movement expressed much greater distrust in parties than those voting for minor parties. Also, now voters that felt close to a party expressed greater distrust in parties. This could be evidence of 5 Star Movement voters having a "party" to feel close to. This pattern is again evident in the results for 2018. Again, the voters for the 5 Star Movement were significantly more distrustful of parties, while voters for more traditional parties had no such effect. We again see that those feeling close to a party do, in fact, have greater distrust in parties. We suggest that this again might be a result of the strong presence of the Five Start Movement and/or the now reemergent Lega. Although identifying with Lega has no independent effect in terms of mistrust.

Table 4 summarizes the results of our analyses. Some general patterns can be detected. While in the 2000s, democratic dissatisfaction correlated with a distrust of parties, by the 2010s this was no longer valid. Parliamentary distrust was the only consistent predictor of distrust in parties. The sign of being close to a party switched between the 2000s and 2010s. A major difference between the 2000s and 2010s that might explain these changes is the emergence of the Five Star Movement. Voters previously distrustful of parties, might be more satisfied with democracy and feel affinity towards the representation provided by the Five Star Movement.

The emergence of this anti-establishment party is expressive of a new way for voters who distrust parties to participate in the political process. Further analysis is needed to understanding the continuing impact of the 5 Star Movement.

We can summarize the findings of our analysis of multiple decades of data in three key points. First, sociodemographic differences had little effect on understanding the source of party resentment. This substantiates the bivariate findings of a lack of cohort effects. Second,

Table 4. Summary of results.

\begin{tabular}{lccccc}
\hline \multirow{2}{*}{ Correlations } & \multicolumn{5}{c}{ Elections } \\
\cline { 2 - 6 } & 2001 & 2006 & 2008 & 2013 & 2018 \\
\hline C1: Democratic Dissatisfaction & + & + & + & $\cdot$ & $\mathrm{n} / \mathrm{a}$ \\
C2: Non-voters & $\cdot$ & + & $\cdot$ & $\cdot$ & $\cdot$ \\
C3: Parliament Trust & + & + & + & + & + \\
C4: General Trust & + &. &. & $\cdot$ & + \\
C5: Close to Party & + &. & + & - & - \\
C6: Party Member & + &. & $\mathrm{n} / \mathrm{a}$ & + & $\mathrm{n} / \mathrm{a}$ \\
C7: Anti-System Voter & $\cdot$ &. & $\cdot$ & + & + \\
\hline
\end{tabular}

$+=$ supported,.$=$ null, $-=$ opposite prediction, N/A $=$ not asked. Source: authors' own elaboration on statistical analysis. distrust in parties correlates well with distrust in parliament and political administration. General social distrust did not translate into a distrust for parties. Thus, we can conclude that discontent can be separated into a political dimension associated with current governance and one of a more systemic nature. Third, while we did not expect it, the rise of the 5 Star Movement as a party that represents a distrust of traditional parties has implications that will continue to affect the future of distrust of parties in Italy, especially now that it is part of the governing coalition. Similar to a case study of New Zealand (Bale and Roberts 2002), electoral reform has not resulted in increased trust in political parties.

\section{CONCLUSIONS}

In this work we have focused on the problem of trust in parties in a particularly relevant case, the Italian one. The result shows that, despite a series of reforms, overall patterns of party distrust have not altered. In toto, the results of this work tell us that socio-demographic differences had little effect on understanding the source of party resentment. Distrust in parties correlates well with distrust in parliament and political administration while general social distrust does not correlate with a distrust for parties.

Of course, Italy as a case study has some particular characteristics, such as the common trope of anti-partitism, the widespread popular criticism of the elites, and the dialectic between political actors in republican Italy since the immediate post-war period. This later aspect is evidenced by the reference to the Giannini's "Uomo Qualunque", the enduring presence and activism of Radical Parties throughout the First Republic pre-2000s, and the 2010s legislative and executive successes of a movement declaredly anti-system: the Five Stars. This later movement has provided a political outlet for anti-party sentiment, as it was the only party whose adherents felt statistically different about the trustworthiness of political parties ${ }^{11}$. In toto, party discontent appears to be able to be split into a political dimension associated with current governance and parties and one of a more systemic nature focus on political institutions themselves (Bergman and Passarelli 2021; Passarelli and Tuorto 2018).

Future research should study more closely the precise mechanisms that promote anti-party sentiment. Our analysis here focused diachronically, but there might be specific factors that impact voters more

\footnotetext{
${ }^{11}$ Similar to findings on the LPF in the Netherlands, our results for the LN are suggestive that their voters are not motivated by political discontent (van der Brug 2003).
} 
strongly in one election than another. Similarly, our analysis did not investigate subnational contextual factors towards party sentiment. There could be regional variation worth exploring perhaps related to economics, government efficiency, corruption, or regional leadership (Van Erkel and Van Der Meer, 2016). Finally, the rhetoric of partisan and non-partisan elites could be examined systemically to further understand how anti-party themes might be transmitted in the public arena.

\section{REFERENCES}

Bale, Tim \& Nigel S. Roberts (2002) Plus ça change ... ? Anti-Party Sentiment and Electoral System Change: A New Zealand Case Study. Commonwealth and Comparative Politics, 40(2), pp.1-20

Bardi, Luciano. (1996) Anti-party sentiment and party system change in Italy. European Journal of Political Research, 29(3), pp.345-363.

Bellucci, Paolo and Paolo. Segatti (eds) (2010) Votare in Italia. Bologna: Il Mulino.

Bergman, Matthew E. and Gianluca Passarelli. (2021) "Conflicting Messages of Electoral Protest: The role of systemic and élite discontent in the Italian 2016 Constitutional Referendum" Politics https://doi. org/10.1177/0263395720974975

Bergman, Matthew E. (2019) Rejecting constitutional reform in the 2016 Italian referendum: analysing the effects of perceived discontent, incumbent performance and referendum-specific factors. Contemporary Italian Politics, 11(2), pp. 177-191.

Bergman, Matthew E. (2020) Mi Piace, ma Non Mi Piaci [I Like It, But I Don't Like You]: Political Knowledge, Interest, and Voting Against the 2016 Italian Referendum. International Journal of Public Opinion Research, 32(4), pp. 801-814 https://doi.org/10.1093/ ijpor/edz048

Cartocci, R, (2007), Mappe del tesoro, Atlante del capitale sociale in Italia, Bologna, Il Mulino

Daalder, Hans (2002) 'Parties: Denied, Dismissed or Redundant'. In R. Gunther, J.R. Montero and J.J. Linz (eds) Political Parties: Old Concepts and New Challenges. Oxford: Oxford University Press, pp. 39-57.

Dalton, Russel J. (1996) Citizen Politics: Public Opinion and Political Parties in Advanced Western Democracies. Chatham, NJ: Chatham House

De Petris, Andrea and Thomas Poguntke (2015) (eds) Anti-Party Parties in Germany and Italy. Protest Movements and Parliamentary Democracy. Roma, Luiss Press.
Gidron, Noam, James Adams and Will Horne. (2020) American Affective Polarization in Comparative Perspective. Cambridge University Press

Hirschman, Albert. O (1970) Exit, Voice, and Loyalty. Responses to Decline in Firms, Organizations, and States. Harvard University press.

Hooghe, M., \& Dassonneville, R. (2018). A spiral of distrust: A panel study on the relation between political distrust and protest voting in Belgium. Government and Opposition, 53(1), 104-130.

Ignazi, Piero (2017) Party and Democracy. The Uneven Road to Party Legitimacy. Oxford: Oxford University Press.

Morlino, Leonardo and Marco Tarchi (1996) The Dissatisfied Society: The Roots of Change in Italy. European Journal of Political Research, 30(1), pp. 41-63

Michael S. Lewis-Beck, Martin Paldam (2000) Economic voting: an introduction, Electoral Studies, 19(2-3), pp. 113-121

Kang, Won-Taek (2004) Protest Voting and Abstention Under Plurality Rule Elections: An Alternative Public Choice Approach. Journal of Theoretical Politics, 16(1), pp. 79-102.

Katsanidou, Alexia and Christina Eder (2018) Vote, party, or protest: The influence of confidence in political institutions on various modes of political participation in Europe. Comparative European Politics 16(2), pp. 290-309.

Kestilä-Kekkonen, Elina (2009) Anti-party sentiment among young adults. Evidence from fourteen West European countries. Young, 17(2), pp. 145-175.

Klingemann, Hans-Dieter, and Dieter Fuchs (eds) (1995) Citizens and the State. Oxford: Oxford University Press.

Mair, Peter (1995) Political Parties, Popular Legitimacy and Public Privilege. West European Politics 18, pp. 40-57.

Maraffi, Marco (2007) Gli italiani e la politica. Bologna: Il Mulino.

Morlino, Leonardo and Marco Tarchi (1996) The dissatisfied society: The roots of political change in Italy. European Journal of Political Research, 29(1), pp. 41-63.

Mudde, Cas (1996) The Paradox of the Anti-party Party: Insights From the Extreme Right. Party Politics, (2), pp. 265-76.

Norris, Pippa (ed) (1999). Critical Citizens: Global Support for Democratic Governance. Oxford: Oxford University Press.

Passarelli, Gianluca (2018) Electoral Systems in Context: Italy. In E. Herron, R. Pekkanen, and M.S. Shugart (eds) The Oxford Handbook of Electoral Systems. Oxford: Oxford University Press, 2018, pp. 851-870. 
Passarelli, G. and Dario Tuorto (2015) A vote(r) like any other? Exploring the protest component in the vote for the Movimento 5 Stelle. In F. Tronconi (ed.) Beppe Grillo's Five Star Movement, Ashgate, pp. 179-194.

Passarelli, Gianluca and Dario Tuorto (2018) The Five Star Movement: purely a matter of protest? The rise of a new party between political discontent and reasoned voting. Party Politics 24(2), pp. 129-140.

Poguntke, Thomas (1996) Anti-party Sentiment: Conceptual thoughts and Empirical Evidence: Explorations into a Minefield. European Journal of Political Research 29, pp. 319-344.

Poguntke, Thomas and Susan E Scarrow (1996) The politics of anti-party sentiment: Introduction. European Journal of Political Research, 29(3), pp. 257-262.

Putnam, R. (2000), Bowling Alone: The Collapse and Revival of American Community, Simon and Schuster, New York

Sani, Giacomo, and Paolo Segatti (2001) 'Antiparty Politics and the Restructuring of the Italian Party System,' in P. N. Diamandouros and R. Gunther, eds., Parties, Politics, and Democracy in the New Southern Europe. Baltimore: The Johns Hopkins University Press, 153-182.

Sartori, Giovanni (1976) Party and Parties Systems. A Framework for Analysis. Cambridge. Cambridge University press.

Schedler, Andreas (1996) Anti-Political-Establishment Parties. Party Politics, 2(3), pp. 291-312.

Torcal, Mariano, Gunther, Richard, and Jose Ramon Montero (2001) Anti-Party Sentiments in Southern Europe, Estudio/Working Paper 2001/170

Torcal, Mariano and Jose Ramon Montero (2006) (eds). Political disaffection in contemporary democracies: social capital, institutions and politics. London - New York: Routledge.

Van der Brug, W. (2003). How the LPF fuelled discontent: Empirical tests of explanations of LPF support. Acta Politica, 38(1), 89-106.

Van Erkel, P. F., \& Van Der Meer, T. W. (2016). Macroeconomic performance, political trust and the Great Recession: A multilevel analysis of the effects of within-country fluctuations in macroeconomic performance on political trust in $15 \mathrm{EU}$ countries, 19992011. European Journal of Political Research, 55(1), 177-197.

Warren, M. (2018). Trust and democracy. In The Oxford handbook of social and political trust, ed. E. Uslaner, 75-94. Oxford: Oxford University Press. 